\title{
SELECTION AND CHARACTERIZATION OF Bacillus thuringiensis ISOLATES WITH A HIGH INSECTICIDAL ACTIVITY AGAINST Spodoptera frugiperda (Lepidoptera: Noctuidae)
}

\author{
SELEÇÃO E CARACTERIZAÇÃO DE ISOLADOS DE Bacillus thuringiensis COM \\ ALTA ATIVIDADE INSETICIDA CONTRA Spodoptera frugiperda (Lepidoptera: \\ Noctuidae)
}

\author{
Fernando Barnabe CERQUEIRA3; Giselly Batista ALVES'; \\ Roberto Franco Teixeira CORRÊA ${ }^{6}$; Érica Soares MARTINS ${ }^{5}$; \\ Luiz Carlos Bertucci BARBOSA ${ }^{4}$; Ildon Rodrigues do NASCIMENTO ${ }^{1}$; \\ Rose Gomes MONNERAT ${ }^{5}$; Bergmann Morais RIBEIRO ${ }^{6}$; Raimundo Wagner de Souza \\ AGUIAR ${ }^{*}$
}

1. Universidade Federal do Tocantins - UFT, Gurupi, TO, Brazil; 2. Engenheira de Bioprocessos e Biotecnologia, Mestranda em Biotecnologia - UFT, Gurupi, TO, Brazil; 3. Agrônomo, Mestre, Doutorando em Biodiversidade e Biotecnologia pela Rede Bionorte, UFT, Palmas, TO, Brazil;; 4.Universidade Federal de Itajubá - Unifei Instituto de Recursos Naturais (IRN); 5. Embrapa Recursos

Genéticos e Biotecnologia, Brasília, DF, Brazil; 6. Instituto de Ciências Biológicas da Universidade de Brasília, DF, Brazil. 1 * Universidade Federal do Tocantins - UFT, Gurupi, TO, Brazil; rwsa@ uft.edu.br

\begin{abstract}
Spodoptera frugiperda (SMITH, 1797) (Lepidoptera: Noctuidae) affects diverse crops of great economic interest, for instance, it can cause severe yield losses in maize, rice and sorghum. In this study, a selection and characterization of Bacillus thuringiensis (BERLINER, 1911) isolates with a high insecticidal activity against $S$. frugiperda was performed. Fifty-two crystal-forming B. thuringiensis isolates that were identified from 3384 Bacillus-like colonies were examined and screened by PCR for the presence cry genes (cry1, cry1Aa, cry1Ab, cry $1 \mathrm{Ac}$, cry $1 \mathrm{D}$, cry 2 and cry $2 \mathrm{Ab}$ ). Four isolates that showed high toxicity towards $S$. frugiperda were shown to harbor cry 2 genes. The crystals were analyzed by electron microscopy and showed bipyramidal and cuboidal shapes. Furthermore, these four isolates had lethal concentration $\left(\mathrm{LC}_{50}\right.$ ) values of $44.5 \mathrm{ng} / \mathrm{cm}^{2}$ (SUFT01), $74.0 \mathrm{ng} / \mathrm{cm}^{2}$ (SUFT02), $89.0 \mathrm{ng} / \mathrm{cm}^{2}$ (SUFT03) and 108 $\mathrm{ng} / \mathrm{cm}^{2}$ (SUFT 04) to neonate $S$. frugiperda larvae. An ultrastructural analysis of midgut cells from $S$. frugiperda incubated with the SUFT01 spore-crystal complex showed disruptions in cellular integrity and in the microvilli of the midgut columnar cells. The isolates characterized in this work are good candidates for the control of S. frugiperda, and could be used for the formulation of new bioinsecticides.
\end{abstract}

KEYWORDS: Cry protein. Spodoptera frugiperda. Entomopathogen. Microbial insecticide. Insect control.

\section{INTRODUCTION}

The Lepidopteran insect Spodoptera frugiperda (Smith, 1797) (Lepidoptera: Noctuidae) affects diverse crops of great economic interest, for instance, it can cause severe yield losses in maize, rice and sorghum (Gallo et al., 2002). Since 35\% of crops are lost to pest damage, an efficient pest control program is an important component in any effort to increase crop yields. The main trouble with the control of this pest is due to this insect behavior, which remains within the plant cartridges, reducing the contact with insecticides applied for its control (BRAGA MAIA et al., 2013). Moreover, in the conventional agricultural systems, the effects caused by changes in biodiversity and instability between trophic levels make the control of $S$. frugiperda increasingly difficult and costly (SANTOSAMAYA et al., 2016; BOREGAS et al., 2013). The chemical control of insects in agriculture has been estimated to cost US\$ 1391 miillion dollars annually in the united states (PIMENTEL, 2005), thus sustainable insect pest control is of vital importance.

Applications of insecticides and growing resistant cultivars are considered effective control methods. However, insecticides are considered generally, harmful to the environment (TODOROVA; KOZHUHAROVA, 2010) and can result in insecticide resistance in the insect pest population. There is an urgent demand to supplement existing management strategies with new methods that improve the insect pest control.

Biological control through the application of bioactive agents or microorganisms that are entomopathogenic to insect pests is an attractive alternative and a sustainable strategy for plant protection (MASSON et al., 1998). The biological control of $S$. frugiperda has been attempted using 
various microorganisms. Bacillus thuringiensis (BERLINER, 1911) (Bt) produces an array of Cry proteins with are potentially toxic to $S$. frugiperda (SANTOS et al., 2009; VALICENTE et al., 2010). The interest in this microorganism stems from its potential as an economical, effective, speciesspecific and environmentally safe pesticide (ARRIETA; ESPINOSA, 2006).

The accumulation of Cry proteins in a $B t$ cell can constitute $20-30 \%$ of the dry weight of the sporulated cell and each crystal protein has in its own insecticidal spectrum (AGAISSE AND LERECLUS, 1995). Some Cry proteins display toxicity to more than one insect order. For example, Cry1I is active against both Lepidoptera and Coleoptera (TAILOR et al., 1992), whereas Cry1B shows toxicity against Lepidoptera, Coleoptera and Diptera (HONGYU et al., 2000). Therefore, Cry proteins have been classified on the basis of their host specificity and their amino acid composition (SCHNEPF et al., 1998; ASOKAN et al., 2012).

The diversity and distribution of $\mathrm{Bt}$ and its cry genes have been described in several reports (CHAK et al., 1994; BRAVO et al., 1998; WANG et al., 2003). Depending on the soil type, different microbial communities are found. Several studies have demonstrated the toxicity of $B$. thuringiensis against $S$. frugiperda obtained from different types of environment. According to observations by Praça et al. (2004) of the $300 \mathrm{Bt}$ isolated from soil samples, only one was effective against $S$. frugiperda with an $\mathrm{LC}_{50}$ of $90.24 \mathrm{ng} / \mathrm{cm}^{2}$. In contrast, have found a larger number of Bt isolates with toxicity against $S$. frugiperda from the surface of leaves (phylloplane) (65\%) and fewer were obtained soil samples (4.7\%) in Colombia (Jara et al (2006). According to observations by Armengol et al. (2007), from $445 \mathrm{Bt}$ isolates of different geographic locations from Colombia only $9.7 \%$ were toxic against $S$. frugiperda. The selection of new isolates of $B t$ that are toxic against $S$. frugiperda and could serve as a source of new cry genes, which could be introduced into economically important plant genomes that need protection against this important pest.

In the present study, soil samples from different regions of the state of Tocantis, Brazil, were used for the screening of $B t$ isolates toxic to $S$. frugiperda. New $B t$ isolates were characterizated and shown potential for further research that may lead to the development of new biopesticides.

\section{MATERIAL AND METHODS}

\section{Isolation of $B$. thuringiensis}

Bacillus-like colonies were isolated from soil samples from different parts of Tocantins State, Brazil, using the method described by Monnerat et al. (2001). The isolates were obtained from rural region the Darcinópolis $\left(6^{\circ} 43^{\prime} 7^{\prime \prime} \mathrm{S}: 47^{\circ} 45^{\prime} 10^{\prime \prime} \mathrm{W}\right)$, Guaraí ( $8^{\circ} 50^{\prime} 4^{\prime \prime}$ S: 48 $30^{\prime} 36^{\prime \prime}$ W), Santa Rita (1051'44" S: 48 $\left.{ }^{\circ} 54^{\prime} 27^{\prime \prime} \mathrm{W}\right)$, Cariri $\left(11^{\circ} 53^{\prime} 25^{\prime \prime} \mathrm{S}\right.$ :

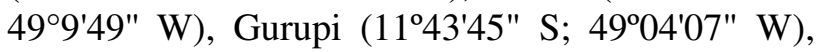

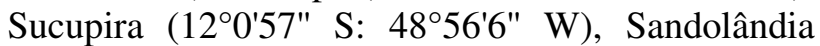
(12³1'37" S: 4956'7" W), Araguaçú (1255'51" S: 4948'59" W), São Salvador (1244'36" S: 48¹4'20" W) and Palmeirópolis $\left(13^{\circ} 2^{\prime} 36^{\prime \prime} \mathrm{S}: 4^{\circ} 24^{\prime} 11^{\prime \prime} \mathrm{W}\right)$ (Figure 1). The soil samples were screened for $\mathrm{Bt}$ on petri dishes with a selective NYSM medium (KALFON et al., 1983) containing $100 \mathrm{mg} / \mathrm{L}$ penicillin $\mathrm{G}$ grown for $24 \mathrm{~h}$ at $30 \pm 0.5^{\circ} \mathrm{C}$ at 180 rpm. After this period, each sample was individually analyzed and identified by phase contrast microscopy ( $\times 1000)$, to verify the presence of inclusion bodies and crystals that allow for the differentiation between $B$. thuringiensis and Bacillus cereus (FRANKLAND; FRANKLAND, 1887).

\section{Insects}

S. frugiperda population with three generations was maintained at the Integrated Pest Management Laboratory of the Federal University of Tocantins. The insects were reared on an artificial diet based on beans, wheat germ and agar, in a controlled room under the following conditions: 26 $\pm 1{ }^{\circ} \mathrm{C}, 70 \pm 10 \%$ relative humidity and a light: dark period of 12:12 h. The adults were fed on an artificial diet according to the procedures described by Martins et al. (2008).

\section{Insect bioassays}

For selective bioassays, a $B t$ suspension was spread on top of the insect diet in 24-well plates (TPP, Techno Plastic Products AG, Switzerland) and one neonate $S$. frugiperda larvae was introduced in each well. Sterile distilled water was used as control, and the mortality was recorded 24 and $48 \mathrm{~h}$ after inoculation. Insect mortality rate was determined by Abbott's formula: $\% \mathrm{M}=(\mathrm{T}-\mathrm{I}) / \mathrm{T} \times$ 100 , where $\% \mathrm{M}=$ percent insect mortality, $\mathrm{T}=$ the number of insects in the control treatment without the application of $\mathrm{Bt}$, and $\mathrm{I}=$ the number of insects treated with Bt (ABBOTT, 1925). 


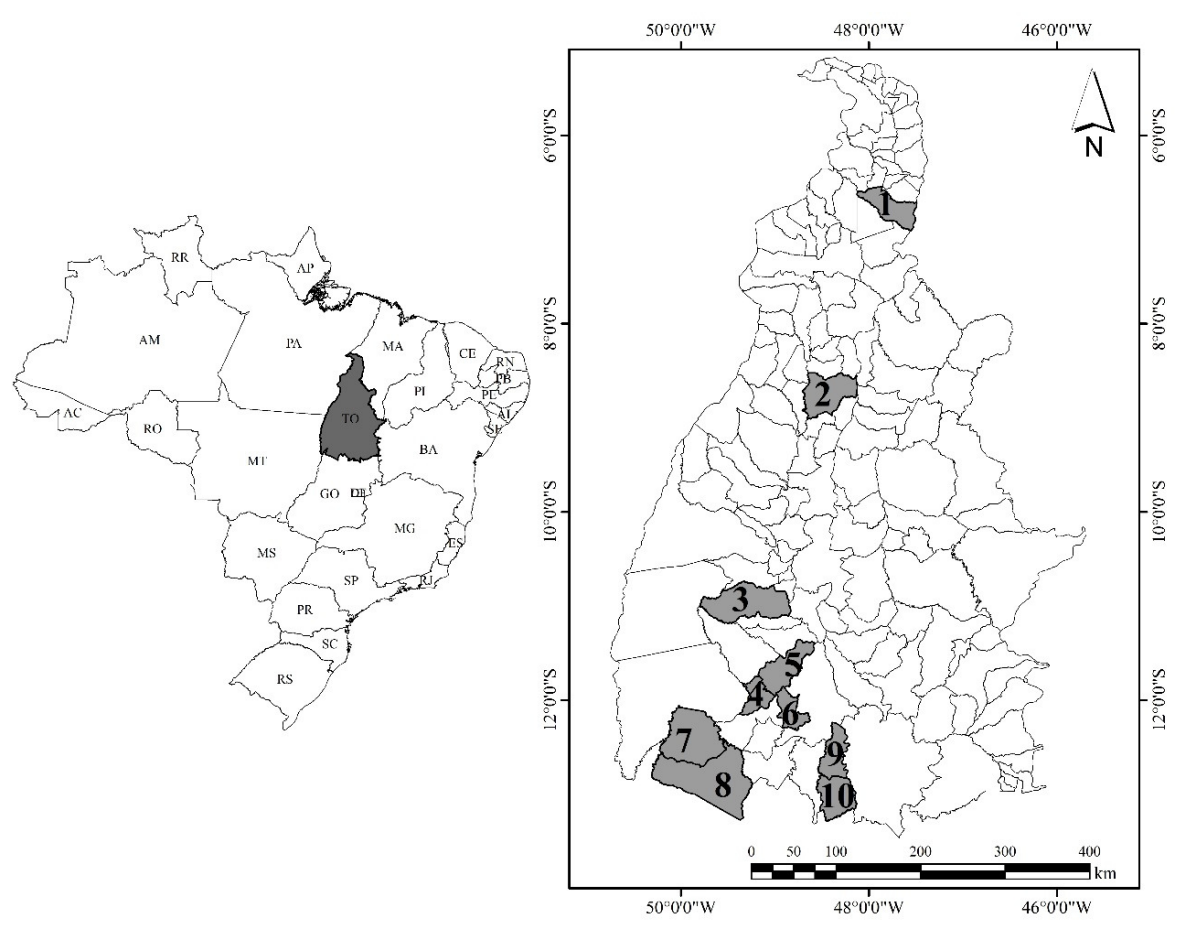

Figure 1. Tocantins State, Brazil, Map indicating the nine cities where the B. thuringiensis isolates were obtained. 1- Darcinópolis; 2- Guaraí; 3- Santa Rita; 4- Cariri; 5- Gurupi ; 6- Sucupira; 7Sandolândia; 8-Araguaçú ; 9- São Salvador; 10: Palmeirópolis.

Dose-response bioassays for the determination of lethal concentration $50\left(\mathrm{LC}_{50}\right)$ were performed with 24 neonate $S$. frugiperda larvae as described by Monnerat et al. (2007), using different doses of dry spores and crystals $(2,23,43,63,83$, $103,123,143,163,183,203,243$ and $263 \mathrm{ng} / \mathrm{cm}^{2}$ ). The insects were kept in an incubator with a photoperiod of $12 / 12 \mathrm{~h}$ (light/dark) at $26^{\circ} \mathrm{C}$. Mortality was recorded at 24 and $48 \mathrm{~h}$, and the $\mathrm{LC}_{50}$ was obtained by a Probit analysis, (FINNEY, 1971), using Polo Plus software (LeOra Software Berkeley, CA, USA). Bacillus thuriengiensis subsp. Kurstaki HD1 (Btk) was used as reference strain and positive control.

\section{Cry gene analysis}

DNA from different isolates of $\mathrm{Bt}$ was purified and used as the template for polymerase chain reaction (PCR) with oligonucleotide primer pairs designed to amplify the cry 1 and $c r y 2$ genes (Cerón et al., 1995; Ben-Dov et al., 1997; Bravo et al., 1998; Lima et al., 2008) (Table 1). PCR was carried out using Taq DNA polymerase (Invitrogen), and the PCR program was performed as follows: $1 \mathrm{~min}$ at $95^{\circ} \mathrm{C} ; 30$ cycles at $95^{\circ} \mathrm{C}$ for 1 min, annealing temperature (established as described in Table 1) and $72^{\circ} \mathrm{C}$ for $1 \mathrm{~min}$, and a final step at $72^{\circ} \mathrm{C}$ for $5 \mathrm{~min}$. The PCR products were analyzed by electrophoresis on 1,2\% agarose gels in TBE buffer ( $400 \mathrm{mM}$ Tris, $10 \mathrm{mM}$ boric acid, and $100 \mathrm{mM}$ EDTA; $\mathrm{pH} 8.0$ ) at $120 \mathrm{~V}$ for $30 \mathrm{~min}$.

\section{Protein analysis by SDS-PAGE}

Proteins from spore/crystal mixtures were obtained according to the protocol described by Lecadet et al. (1992). Proteins were suspended in a small volume of phosphate-buffered saline $(136 \mathrm{mM}$ $\mathrm{NaCl}, 1.4 \mathrm{mM} \mathrm{KH} \mathrm{KO}_{4}, 2.6 \mathrm{mM} \mathrm{KCl}, 8 \mathrm{mM}$ $\mathrm{Na}_{2} \mathrm{HPO}_{4}$ and $4.2 \mathrm{~mL} \quad \mathrm{H}_{2} \mathrm{O}, \mathrm{pH}$ 7.4), and fractionated by electrophoresis in $12 \%$ SDS-PAGE gels ( Sambrook et al., 2001).

\section{Ultrastructural characterization of spores and Cry proteins}

The ultrastructural characterization of the spores and Cry proteins from B. thuringiensis isolates was performed by scanning electron microscopy. The isolates were cultivated in NYSM agar medium at $30^{\circ} \mathrm{C}$ for $72 \mathrm{~h}$ and then a loop of the isolate was collected and diluted in sterile water. A volume of $100 \mu \mathrm{L}$ of this dilution was deposited over metallic supports to be dried for $24 \mathrm{~h}$ at $37^{\circ} \mathrm{C}$, covered with gold for $180 \mathrm{~s}$ using an Emitech apparatus (model K550), and observed in a Zeiss scanning electron microscope (model DSM 962) at 10 or $20 \mathrm{Kv}$. 
Table 1. Primers that recognize the cry 1 , cry $1 \mathrm{Aa}$, cry $1 \mathrm{Ab}$, cry $1 \mathrm{Ac}$, cry $1 \mathrm{D}$, cry 2 and cry $2 \mathrm{Ab}$ genes of Bacillus thuringiensis and the expected PCR amplicon size.

\begin{tabular}{|c|c|c|c|c|c|}
\hline Gene & Sequence of primer $(\mathrm{F})$ & Sequence of primer $(\mathrm{R})$ & $\begin{array}{l}\text { Prod. } \\
\text { (bp) }\end{array}$ & $\begin{array}{l}\text { Ann. temp. } \\
\left({ }^{\mathrm{O}} \mathrm{C}\right)\end{array}$ & Reference \\
\hline cryl & $\begin{array}{c}\text { CTGGATTTACAGGTGGGGAT } \\
\text { AT }\end{array}$ & TGAGTCGCTTCGCATATTTGACT & 558 & 52 & (Bravo et al., 1998) \\
\hline crylAa & $\begin{array}{c}\text { TGTAGAAGAGGAAGTCTATC } \\
\text { CA }\end{array}$ & TATCGGTTTCTGGGAAGTA & 272 & 48 & (Ceron et al., 1995) \\
\hline $\operatorname{cryl} \mathrm{Ab}$ & $\begin{array}{c}\text { TGTAGAAGAGGAAGTCTATC } \\
\text { CA }\end{array}$ & TATCGGTTTCTGGGAAGTA & 284 & 48 & (Ceron et al., 1995) \\
\hline crylAc & $\begin{array}{c}\text { TGTAGAAGAGGAAGTCTATC } \\
\text { CA }\end{array}$ & TATCGGTTTCTGGGAAGTA & 272 & 48 & (Ceron et al., 1995) \\
\hline crylD & $\begin{array}{c}\text { TGTAGAAGAGGAAGTCTATC } \\
\text { CA }\end{array}$ & TGTAGAAGAGGAAGTCTATCCA & 284 & 48 & (Ceron et al., 1995) \\
\hline cry 2 & $\begin{array}{c}\text { GTTATTCTTAATGCAGATGAA } \\
\text { TGGG }\end{array}$ & GAGATTAGTCGCCCCTATGAG & 498 & 54 & (Ben-Dov et al., 1997) \\
\hline $\operatorname{cry} 2 \mathrm{Ab}$ & $\begin{array}{c}\text { GGGATCCATGAATAATGTAT } \\
\text { TGAATAGTGGAAG }\end{array}$ & $\begin{array}{l}\text { GGGATCCTTAATAAAGTGGTGG } \\
\text { AAGATTAGTTGGC }\end{array}$ & 1990 & 52 & (Lima et al., 2008) \\
\hline
\end{tabular}

$\mathrm{F}=$ specific forward primers; $\mathrm{R}=$ specific reverse primers, Ann. Temp - Annealing temperature $\left({ }^{\circ} \mathrm{C}\right)$.

\section{Analysis of $S$. frugiperda midguts}

Neonate S. frugiperda larvae were fed an artificial diet containing a suspension of $\mathrm{Bt}$. Inoculated larvae were collected $24 \mathrm{~h}$ after diet ingestion, and the midguts were removed and processed for transmission electron microscopy, according to the protocol described by Martins et al. (2008). Ultra-thin sections were cut in an ultramicrotome (Leika ultracut UCT) and observed in a JEOL 1011 at $80 \mathrm{kV}$.

\section{Colony forming units (CFUs) and $\delta$-endotoxin production}

The CFU and $\delta$-endotoxin production of the $\mathrm{Bt}$ isolates were assessed in CCY medium (Stewart et al., 1981) after $72 \mathrm{~h}$ at $30^{\circ} \mathrm{C}$ in a rotary shaker set at $200 \mathrm{rpm}$ (ZOUARI et al., 2002; AZZOUZ et al., 2014). The number of spores and the $\delta$-endotoxin production were determined as described by Ghribi et al. (2007).

\section{RESULTS AND DISCUSSION}

\section{Isolation of $B$. thuringiensis isolates}

In total, 52 crystal-forming $B$. thuringiensis isolates were identified from 3384 Bacillus-like colonies isolated from soil samples (Table 2). Only 37 showed any toxicity to $S$. frugiperda larvae (Table 3). The occurrence of Bt having higher levels of toxicity towards $S$. frugiperda was more prevalent in soil samples from the south-west region of Tocantins State (Araguaçu and Sandolândia), including four isolates that induced more than an $80 \%$ mortality in neonate S. frugiperda larvae. Isolates obtained from Palmas, Guaraí were less toxic to $S$. frugiperda, with induced mortalities of less than $15 \%$ (Table 3). In this study, $71.2 \%$ of Bt isolates showed toxicity against $S$. frugiperda. As can be seen from these results, the Bt isolates toxic to $S$. frugiperda can be found in different sample types and regions. These isolates have the potential to encode new combinations of cry genes or new cry genes.

Table 2. Bacillus thuringiensis $(\mathrm{Bt})$ isolates from soil samples from Tocantins State, Brazil.

\begin{tabular}{ccccc}
\hline Origin $^{\mathrm{a}}$ & $\begin{array}{c}\text { No. of samples } \\
\text { Collected }\end{array}$ & $\begin{array}{c}\text { No. of Bt } \\
\text { colonies screened }\end{array}$ & $\begin{array}{c}\text { No. of Bt } \\
\text { isolates obtained }\end{array}$ & $\begin{array}{c}\text { Bt isolation } \\
\text { index }^{\mathrm{b}}\end{array}$ \\
\hline GUR 1 & 8 & 123 & 3 & 0.024 \\
GUR 2 & 7 & 146 & 1 & 0.007 \\
GUR 3 & 7 & 80 & 1 & 0.013 \\
GUR 4 & 4 & 73 & 1 & 0.014 \\
GUR 5 & 4 & 98 & 1 & 0.010 \\
GUR 6 & 6 & 79 & 1 & 0.013 \\
GUR 7 & 6 & 67 & 1 & 0.015 \\
GUR 8 & 10 & 123 & 2 & 0.016 \\
GUR 9 & 14 & 176 & 1 & 0.006 \\
ARA 1 & 10 & 78 & 2 & 0.026 \\
ARA 2 & 14 & 129 & 3 & 0.023
\end{tabular}




$\begin{array}{ccccc}\text { ARA 3 } & 7 & 103 & 1 & 0.010 \\ \text { ARA 4 } & 10 & 75 & 3 & 0.040 \\ \text { ARA 5 } & 10 & 87 & 1 & 0.011 \\ \text { PAL 1 } & 4 & 108 & 1 & 0.009 \\ \text { PAL 2 } & 3 & 176 & 1 & 0.006 \\ \text { PAL 3 } & 4 & 144 & 1 & 0.007 \\ \text { PAL 4 } & 4 & 128 & 1 & 0.008 \\ \text { PAL5 } & 7 & 88 & 1 & 0.011 \\ \text { SS 1 } & 23 & 45 & 1 & 0.022 \\ \text { SS 2 } & 14 & 156 & 1 & 0.010 \\ \text { SU 1 } & 23 & 145 & 1 & 0.006 \\ \text { SU 2 } & 6 & 98 & 2 & 0.014 \\ \text { DAR 1 } & 4 & 95 & 1 & 0.010 \\ \text { DAR 2 } & 7 & 82 & 1 & 0.011 \\ \text { DAR 3 } & 8 & 64 & 1 & 0.012 \\ \text { CAR 1 } & 9 & 36 & 2 & 0.031 \\ \text { CAR 2 } & 8 & 29 & 1 & 0.028 \\ \text { SR 1 } & 4 & 45 & 1 & 0.034 \\ \text { SR 2 } & 3 & 56 & 1 & 0.022 \\ \text { GUA 1 } & 6 & 72 & 2 & 0.036 \\ \text { SAN 1 } & 8 & 70 & 1 & 0.014 \\ \text { SAN 2 } & 10 & 3.384 & 1 & 0.014 \\ \text { Total } & 303 & 52 & 0.015\end{array}$

${ }^{\text {a }}$ First column shows the district of origin of each isolate -GUR: Gurupi; ARA: Araguaçú; PALM: Palmerópolis; SS: São Salvador; SU: Sucupira; SAN: Sandolândia; CAR: Cariri; DAR: Darcinopolis; SR: Santa Rita; GUA: Guarai); ${ }^{\mathrm{b}}$ Bt isolation index calculated by dividing the population of crystalliferous $B t$ isolates by the total Bacillus population of each sample collected.

In this work, $\mathrm{Bt}$ isolates were found in both clay and sandy soils. Our data also indicated the occurrence of $\mathrm{Bt}$ isolates with higher toxicities to $S$. frugiperda in clay soil samples (Table 3 ). Intensive screening programs have isolated and characterized new isolates with different combinations of crystal proteins resulting in the discovery of new toxins and toxins with a broader activity spectrum (BRAVO et al., 1998).

Table 3. List of Bacillus thuringiensis (Bt) isolates that showed toxic activity against Spodoptera frugiperda. The data show the polypeptide and gene (cry1 and cry2) profiles, crystal morphology and \% mortality rate for the spore/crystal mixture of each isolate in a selective bioassay.

\begin{tabular}{|c|c|c|c|c|c|c|c|}
\hline $\mathrm{N}$. & Origin $^{a}$ & Soils & Bt isolate & $\begin{array}{l}\text { Polypept. } \\
(\mathrm{kDa})\end{array}$ & $\begin{array}{l}\text { Crystal } \\
\text { morphol. }\end{array}$ & Mort. (\%) & cry genes \\
\hline 1 & GUR 1 & clay & SUFT 5 & $\mathrm{Nd}$ & NF & $30 \%$ & cry 1 \\
\hline 2 & GUR 2 & clay & SUFT 9 & $\mathrm{Nd}$ & NF & $50 \%$ & cry 1 \\
\hline 3 & GUR 3 & clay & SUFT 10 & 130 & NF & $40 \%$ & cry 1, cry $1 \mathrm{Aa}$ \\
\hline 4 & GUR 4 & clay & SUFT 11 & 130 & NF & $40 \%$ & cry 1 \\
\hline 5 & GUR 5 & clay & SUFT 14 & 130 & NF & $45 \%$ & cry 1, cry $1 \mathrm{Aa}$, cry $1 \mathrm{Ab}$, cry $1 \mathrm{Ac}$ \\
\hline 6 & GUR 6 & clay & SUFT 12 & $140 / 70$ & Bip & $55 \%$ & cry 1, cry $1 \mathrm{Aa}$, cry $1 \mathrm{Ac}$ \\
\hline 7 & GUR 7 & clay & SUFT 23 & $130 / 70$ & Bip & $45 \%$ & cry 1 \\
\hline 8 & GUR 8 & clay & SUFT 41 & 70 & Bip & $50 \%$ & cry 1, cry $1 \mathrm{Ab}$, cry $1 \mathrm{Ac}$ \\
\hline 9 & GUR 9 & clay & SUFT 08 & 70 & Bip & $45 \%$ & cry 1, cry $1 \mathrm{Ac}$ \\
\hline 10 & ARA 1 & clay & SUFT 16 & 130 & Bip & $50 \%$ & cry 1, cry $1 \mathrm{Aa}$, cry $1 \mathrm{Ac}$ \\
\hline 11 & ARA 2 & clay & SUFT 06 & 130 & $\mathrm{Bip} / \mathrm{Cub}$ & $25 \%$ & cry 1 \\
\hline 12 & ARA 3 & clay & SUFT 07 & $\mathrm{Nd}$ & NF & $25 \%$ & cry 1 \\
\hline 13 & ARA 4 & clay & SUFT 02 & $140 / 70$ & $\mathrm{Bip} / \mathrm{Cub}$ & $85 \%$ & $\begin{array}{l}\text { cry } 1, \text { cry } 1 \mathrm{Aa}, \text { cry } 1 \mathrm{Ab}, \text { cry } 1 \mathrm{Ac} \\
\text { cry } 1 \mathrm{D}, \text {, cry } 2, \text { cry } 2 \mathrm{Ab}\end{array}$ \\
\hline 14 & ARA 5 & clay & SUFT 04 & 70 & $\mathrm{Cub}$ & $80 \%$ & cry 1, cry $1 \mathrm{Aa}$, cry $1 \mathrm{Ab}$, cry $1 \mathrm{Ac}$, \\
\hline
\end{tabular}




\begin{tabular}{|c|c|c|c|c|c|c|c|}
\hline & & & & & & & cry 2 \\
\hline 15 & PAL 1 & clay & SUFT 24 & $\mathrm{Nd}$ & NF & $20 \%$ & cry 1 \\
\hline 16 & PAL 2 & clay & SUFT 26 & $\mathrm{Nd}$ & $\mathrm{NF}$ & $20 \%$ & cry 1 \\
\hline 17 & PAL 3 & clay & SUFT 32 & 70 & $\mathrm{NF}$ & $20 \%$ & cry 1, cry $1 \mathrm{Ac}$ \\
\hline 18 & PAL 4 & clay & SUFT 31 & $130 / 70$ & Bip & $10 \%$ & cry 1, cry $1 \mathrm{Ab}$, cry $1 \mathrm{Ac}$ \\
\hline 19 & PAL5 & clay & SUFT 44 & $130 / 70$ & Bip & $60 \%$ & cry 1, cry $1 \mathrm{Ab}$, cry $1 \mathrm{Ac}$ \\
\hline 20 & SS 1 & sandy & SUFT 24 & 130 & Bip & $50 \%$ & cry 1, cry $1 \mathrm{Ac}$ \\
\hline 21 & SS 2 & sandy & SUFT 18 & 140 & Bip & $45 \%$ & cry 1, cry $1 \mathrm{Ab}$, cry $1 \mathrm{Ac}$ \\
\hline 22 & SU 1 & clay & SUFT 19 & 70 & Bip & $45 \%$ & cry 1, cry $1 \mathrm{Ab}$, cry $1 \mathrm{Ac}$ \\
\hline 23 & SU 2 & clay & SUFT 15 & 70 & Bip & $45 \%$ & cry 1, cry $1 \mathrm{Aa}$ \\
\hline 24 & DAR 1 & clay & SUFT 13 & $130 / 70$ & $\mathrm{Bip} / \mathrm{Cub}$ & $45 \%$ & cry 1, cry $1 \mathrm{Ab}$ \\
\hline 25 & DAR 2 & sandy & SUFT 49 & $\mathrm{Nd}$ & $\mathrm{NF}$ & $15 \%$ & cry 1 \\
\hline 26 & DAR 3 & sandy & SUFT 37 & $\mathrm{Nd}$ & $\mathrm{NF}$ & $35 \%$ & cry 1 \\
\hline 27 & CAR 1 & sandy & SUFT 36 & $\mathrm{Nd}$ & $\mathrm{NF}$ & $30 \%$ & cry 1 \\
\hline 28 & CAR 2 & sandy & SUFT 39 & $\mathrm{Nd}$ & $\mathrm{NF}$ & $15 \%$ & cry 1 \\
\hline 29 & SR 1 & sandy & SUFT 42 & 130 & Bip & $25 \%$ & cry 1, cry $1 \mathrm{Ac}$ \\
\hline 30 & SR 2 & sandy & SUFT 34 & $\mathrm{Nd}$ & $\mathrm{NF}$ & $15 \%$ & cry 1 \\
\hline 31 & GUA 1 & sandy & SUFT 38 & $\mathrm{Nd}$ & $\mathrm{NF}$ & $10 \%$ & cry 1 \\
\hline 32 & SAN 1 & clay & SUFT 01 & $140 / 70$ & $\mathrm{Bip} / \mathrm{Cub}$ & $90 \%$ & $\begin{array}{l}\text { cry } 1, \text { cry } 1 \mathrm{Aa}, \text { cry } 1 \mathrm{Ab}, \text { cry } 1 \mathrm{Ac}, \\
\text { cry } 1 \mathrm{D}, \text { cry } 2, \text { cry } 2 \mathrm{Ab}\end{array}$ \\
\hline 33 & SAN 2 & clay & SUFT 03 & $140 / 70$ & Bip/Cub & $80 \%$ & $\begin{array}{l}\text { cry } 1, \text { cry } 1 \mathrm{Aa} \text { cry } 1 \mathrm{Ab}, \text { cry } 1 \mathrm{Ac}, \\
\text { cry } 2\end{array}$ \\
\hline
\end{tabular}

$\mathrm{Nd}=$ not determined, $\mathrm{NF}=$ not found, $\mathrm{Bip}=$ bipyramidal, $\mathrm{Cub}=$ cuboidal.

\section{Insect bioassays}

The four isolates that produced $80 \%$ or more larval mortality in the selective assay were selected for analysis using the dose-response bioassay. SUFT01 showed the highest toxicity with an $\mathrm{LC}_{50}$ of $44.5 \mathrm{ng} / \mathrm{cm}^{2}$, while isolates SUFT02, SUFT03 and SUFT04 had LC $_{50}$ values of 74.0, 89.0 and $108 \mathrm{ng} / \mathrm{cm}^{2}$, respectively (Table 4$) . S$. frugiperda has shown a variable susceptibility to different $B t$ toxins, probably related to the genetic variability among different populations of the insect (MONNERAT et al., 2007).
At the same time, some Cry proteins were shown to be non-toxic to $S$. frugiperda (ARANDA et al., 1996; LUTTRELL et al., 1999). Santos et al. (2009) evaluated the effects of one $B$. thuringiensis subsp. aizawai and several B. thuringiensis subsp. kurstaki isolates against $S$. frugiperda. They found that, in general, most isolates of $B t$ were not toxic or showed low toxicity towards $S$. frugiperda larvae. Dias et al. (1999) also found that out of $25 \mathrm{Bt}$ isolates, only eight had a high toxicity towards $S$. frugiperda larvae.

Table 4. $\mathrm{LC}_{50}$ values of Bacillus thuringiensis (Bt) isolates that have activity against Spodoptera frugiperda larvae.

\begin{tabular}{|c|c|c|c|c|c|c|}
\hline$B t$ isolate & $\mathrm{n}^{\mathrm{a}}$ & Slope $\pm \mathrm{SE}$ & $\begin{array}{c}\mathrm{LC}_{50}\left(\mathrm{FL}^{\mathrm{b}}\right) \\
\left(\mathrm{ng} / \mathrm{cm}^{2}\right)^{c}\end{array}$ & $\mathrm{LC}_{95}\left(\mathrm{FL}^{\mathrm{b}}\right)\left(\mathrm{ng} / \mathrm{cm}^{2}\right)^{c}$ & $\chi^{2 \mathbf{d}}$ & $P$ \\
\hline SUFT01 & 25 & $1.08 \pm 0.12$ & $44.5(22.7-61.0)$ & $104.5(91.0-142.23)$ & 1.717 & 0.16 \\
\hline SUFT02 & 25 & $2.04 \pm 0.21$ & $74.0(31-150)$ & $194.0(171-225)$ & 3.944 & 0.21 \\
\hline SUFT03 & 25 & $1.48 \pm 0.20$ & $89.0(72.5-106)$ & $198(172.5-211.2)$ & 0.325 & 0.23 \\
\hline SUFT04 & 25 & $1.34 \pm 0.21$ & $108(72-220)$ & $218(199-241)$ & 1.960 & 0.29 \\
\hline
\end{tabular}

\section{Identification of cry genes}

Predictions of insecticidal activities were made based on the cry gene content of the isolates as determined by PCR analysis. All isolates were shown to have cry genes when screened with a general cry1-specific primer pair designed by Bravo et al. (1998) (Table 2, Figure 2). Using specific cry primers, the cryl gene was detected in all isolates, the $\operatorname{cry} 1 \mathrm{Ac}$ gene was the most present with $45.9 \%$ (17 isolates), followed by the cry $1 \mathrm{Ab}$ gene with 
$32.4 \%$ (12 isolates), cry 1 Aa with $18.9 \%$ (9 isolates), cry $1 \mathrm{D}$ with $5.4 \%$ (2 isolates), cry 2 with $10,8 \%$ (4 isolates) and $c r y 2 \mathrm{Ab}$ with $5,4 \%$ (2 isolates) (Figure 2). Different Bt screening programs worldwide have identified the cry 1 genes as the most common crytype gene (BRAVO et al., 1998; URIBE et al., 2003; BERÓN; SALERMO, 2006; SU et al., 2007; GAO et al., 2008; SANTOS et al., 2009; VALICENTE et al., 2010).

Isolates that harbored cryl, cry $1 \mathrm{Aa}$, cry $1 \mathrm{Ab}$, cry $1 \mathrm{Ac}$, cry $1 \mathrm{D}$, cry 2 and cry $2 \mathrm{Ab}$ were more toxic to S. frugiperda (Table 3). Valicente et al. (2010) suggested that the toxicity of different Brazilian $B$. thuringiensis isolates to $S$. frugiperda was related to their cry 1 gene content. The cry genes frequencies and profiles differ among worldwide Bt collections based on region, moreover, they reported that the genes most frequently found in Minas Gerais, Amazonas, Paraná and São Paulo State, Brazil were cry $1 \mathrm{D}$, cry $1 \mathrm{G}$, cry $1 \mathrm{~B}$ and cry $1 \mathrm{E}$, respectively.

Since the toxic activity of any Bt isolate is due to the combination of different Cry proteins, we attempted to identify some common cry 1 and cry 2 genes present in a collection of $B t$ isolates, which had any level of toxicity to $S$. frugiperda, from Tocantins State (Brazil). The high toxicity of the four isolates of $\mathrm{Bt}$ may be associated with the presence of both the cry1 and cry2 genes (Table 3). In addition, several factors could be implicated in the insecticidal activity of the four isolates such as: different expression levels of crylA and cry 2 genes and the specific proportions of delta-endotoxins present in the crystal; mutations in cry genes and the presence of unknown Cry toxins in the crystal (CHENG et al., 1999; TOUNSI et al., 2006; HIRE et al., 2008). Moreover, the toxicity of Bt isolates against $S$. frugiperda is associated combinations of cry genes. Bravo et al. (1998), showed the combination of cry1D and cry $1 \mathrm{C}$ genes exhibit high toxicity $\mathrm{LC}_{50}$ against $S$. frugiperda below $35 \mathrm{ng} /$ $\mathrm{cm}^{2}$. Similar results were observed by Jara et al. (2006) with combinations of cry1 Aa, cry1Ac, cry1D and cry $1 \mathrm{~b}$ genes showing $\mathrm{LC}_{50}$ of $29 \mathrm{ng} / \mathrm{cm}^{2}$. In the present study we observed that Bt isolated with higher toxicity (SUFT01) against $S$. frugiperda had combinations of cry $1 \mathrm{Aa}$, cry $1 \mathrm{Ab}$, cry $1 \mathrm{Ac}$, cry $1 \mathrm{D}$, cry 2 and cry $2 \mathrm{Ab}$ genes and $\mathrm{LC}_{50}$ of $44.5 \mathrm{ng} / \mathrm{cm}^{2}$ (Table 4).

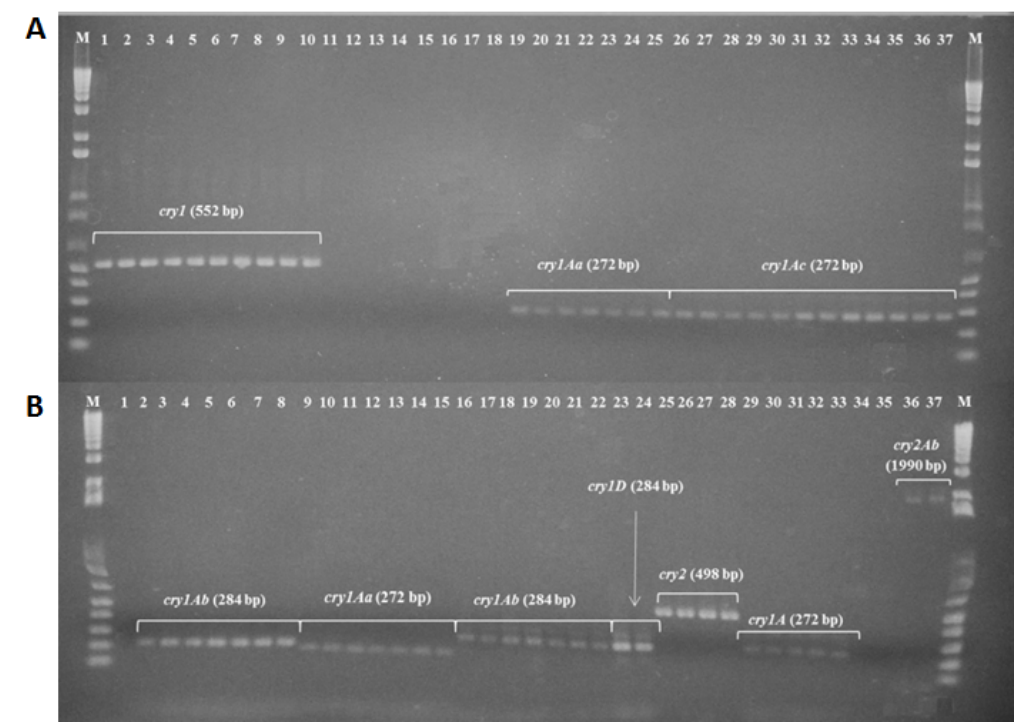

Figure 2. Screening of 37 Bacillus thuringiensis $(\mathrm{Bt})$ isolates for the presence of cry 1 and cry 2 genes from PCR amplification. A: PCR amplification of cry1-specific oligonucleotides in lanes 1 to 10 ( 552 bp); cry $1 \mathrm{Ab}$ specific oligonucleotides in lanes 11 to 18 (no PCR amplification); cry1Aa-specific oligonucleotides in lanes 19 to 25 ( 272 bp) and cry1Ac-specific oligonucleotides in lanes 26 to 37 ( 272 bp). B. PCR amplification of cry1 Ab genes in lanes 2 to $8(\sim 284 \mathrm{bp})$; cry1Aa genes in lanes 9 to $15(\sim 272 \mathrm{bp})$; cry1 Ab genes in lanes 16 to $22(\sim 284 \mathrm{bp})$; cry1D genes in lanes 23 to $24(\sim 284 \mathrm{bp})$; cry 2 genes in lanes 25 to $28(\sim 498$ bp); cry $1 \mathrm{Ac}$ genes in lanes 29 to $33(\sim 272 \mathrm{bp})$; crylAc-specific oligonucleotides in lanes 34 and 35 (no PCR amplification produced); cry2Ab -specific oligonucleotides in lanes 36 and 37 (1990 bp).

\section{Crystal protein patterns and morphologies}

The protein profiles of purified crystals from isolates SUFT01, SUFT02, SUFT03 and SUFT04 were analyzed using SDS-PAGE and showed polypeptides of $\sim 70$ and $140 \mathrm{kDa}$ (Table 3, 
Figure 3). An ultrastructural analysis of thespore/crystal mixtures from SUFT01, SUFT02 and SUFT03 isolates showed the presence of bipyramidal and cuboidal crystals (Figure 4A, B and
C). The SUFT04 isolate showed only cuboidal crystals (Figure 4D). The different profiles could be the result of different toxins being produced in these isolates.

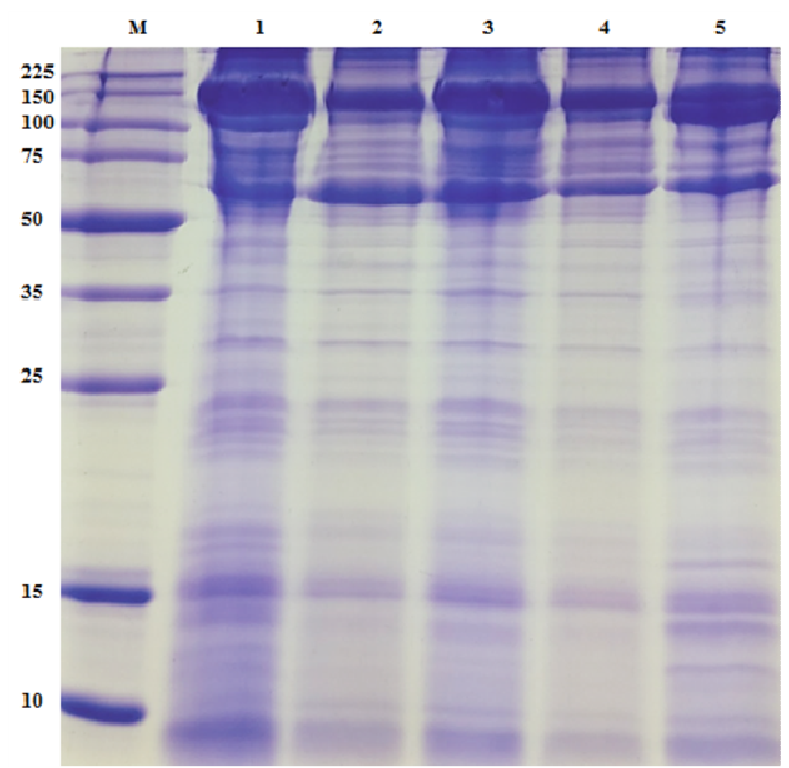

Figure 3. SDS-PAGE of Bacillus thuringiensis crystal proteins from selected isolates. Spore/crystal preparations from sporulated cultures were subjected to electrophoresis in bis-acrylamide gels. $\mathrm{M}$ - M1, Molecular weight marker; 1- HD1 - strain of B. thuringiensis; 2, SUFT01 isolate; 3, SUFT02 isolate; 4, SUFT03 isolate; and 5, SUFT04 isolate.
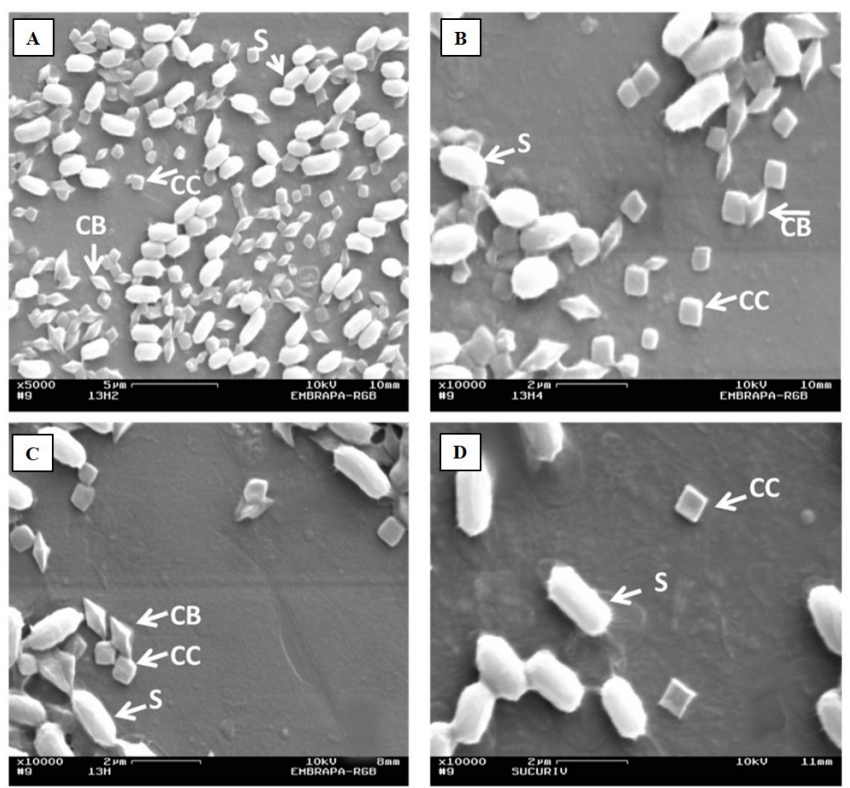

Figure 4. Ultrastructural analysis of the spore/crystal mixtures obtained from selected isolates of Bacillus thuringiensis obtained from Tocantins State, Brazil. A. SUFT01 isolate, B. SUFT02 isolate, C. SUFT03 isolate, and D. SUFT04 isolate. Arrows: S, spores; CC, cuboidal crystals; and CB, bipyramidal crystals.

The analysis of the $\mathrm{Bt}$ isolates revealed that from 37 isolates analyzed, 12 formed bipyramidal crystals (Table 3), similar to isolates active against Lepidoptera (PRAÇA et al., 2004). However, 5 isolates that exhibited toxicity to $S$. frugiperda showed cuboidal and bipyramidal crystal inclusions (Table 3). The presence of a particular crystal type is not always associated with the toxicity towards an 
insect order. For example, Cry1I is active against both Lepidoptera and Coleoptera (TAILOR et al., 1992), whereas Cry1B shows toxicity against Lepidoptera, Coleoptera and Diptera (HONGYU et al., 2000). SUFT04 isolate formed cuboidal crystals and the presence of $\sim 140 \mathrm{kDa}$ band in SDS-PAGE. The $\sim 140 \mathrm{kDa}$ band is usually associated with the formation of bipyramidal crystals. This absence of bipyramidal crystals could be due to the expression of a mutated version of a Cry protein or interaction of more than one Cry protein to produce the cuboidal crystal or even to the presence of a different Cry or other unrelated protein of the same size.

Several Bt toxins have already been identified and their toxicity to $S$. frugiperda has been demonstrated. However, new toxins are still being discovered. That diversity of these toxins includes activity against protozoans, mites, sheep lice, bark beetles, cockroaches, grasshoppers, tephritid fruit flies, moth flies and delphacids (FRANKENHUYZEN, 2009). Specific toxins responsible for those activities have not yet been identified or are still being characterized (SONG et al., 2008).

\section{CFUs and $\delta$-endotoxin production}

The CFU and $\delta$-endotoxin production of the selected isolates showed that SUFT01 produced $2,678.90 \pm 31.6 \mathrm{mg} \mathrm{L}^{-1} \delta$-endotoxin, which was similar quantity to the $2,602.25 \pm 14.27 \mathrm{mg} \mathrm{L}^{-1} \delta$ endotoxin produced by SUFT03, but superior to the $2,469.74 \pm 19.7,2,337.12 \pm 8.45$ and $2,425.17 \pm$ $26.70 \mathrm{mg} \mathrm{L}^{-1} \delta$-endotoxin produced by SUFT02, SUFT04 and HD1, respectively (Table 5). SUFT01 produced $87.12( \pm 9.01) \times 10^{9} \mathrm{CFUs} / \mathrm{L}$, which was fewer than the $120( \pm 12.14)$ and $101( \pm 1.28) \times 10^{9}$ CFUs /L produced by SUFT02 and SUFT03, respectively, while lower CFU numbers, 60.45 ( \pm $4.25)$ and $76.56( \pm 10.01) \times 10^{9} \mathrm{CFUs} / \mathrm{L}$, were produced by SUFT04 and HD1, respectively (Table 5). A careful study of additional fermentation conditions revealed that the complexes of SUFT01 and SUFT02 spores and crystals showed high levels of insecticidal activities than when was performed the selective bioassays $(100 \%$ mortality).

Table 5. $\delta$-endotoxin production of selected Bacillus thuringiensis (Bt) isolates on a CCY medium at 72 hours.

\begin{tabular}{cccc}
\hline Bt isolate & Toxins $(\mathrm{mg} / \mathrm{L})$ & CFUs $\left(10^{9}\right.$ spores/L) & $\begin{array}{c}\text { Activity against Spodoptera frugiperda larvae } \\
\left(120 \mathrm{ng} / \mathrm{cm}^{2}\right)\end{array}$ \\
\hline SUFT01 & $2.678,90 \pm 31.6 \mathrm{a}$ & $87.12 \pm 9.01 \mathrm{a}$ & $100 \pm 0.0 \mathrm{~b}$ \\
SUFT02 & $2.469,74 \pm 19.7 \mathrm{~b}$ & $120 \pm 12.14 \mathrm{a}$ & $100 \pm 0.0 \mathrm{~b}$ \\
SUFT03 & $2.602,25 \pm 14.27 \mathrm{a}$ & $101 \pm 1.28 \mathrm{~b}$ & $70 \pm 10.05 \mathrm{a}$ \\
SUFT04 & $2.337,12 \pm 8.45 \mathrm{c}$ & $60.45 \pm 4.25 \mathrm{~b}$ & $55.12 \pm 5.01 \mathrm{c}$ \\
HD1 & $2.425,17 \pm 26.70 \mathrm{c}$ & $76.56 \pm 10.01 \mathrm{~b}$ & $92.01 \pm 12.0 \mathrm{~b}$ \\
\hline
\end{tabular}

Results are expressed as means \pm standard error. Data represent the means of six replicates. Means in the same column followed by different letters are significantly different $(\mathrm{p}<0.05)$. Analysis of variance by Tukey's test.

The high toxicity of SUFT01 may be associated with the cry gene copy number and could be a factor in $\delta$-endotoxin overproduction. Other studies also demonstrated that the $B t$ isolates with greater cry $1 \mathrm{~A}$ gene copy numbers produced more $\delta$ endotoxin than did the reference strain HD1 (SAADAOUI et al., 2009).

Additionally, Azzouz et al. (2014) showed that $\delta$-endotoxin production by two Bt isolates that had high insecticidal activity against Spodoptera littoralis (BOISDUVAL, 1833) (Lepidoptera: Noctuidae) produced 43.71 and $80.81 \%$ more $\delta$ endotoxin than HD1. The spore and $\delta$-endotoxin production of $\mathrm{Bt}$ isolates obtained in this work indicates the potential for using formulations, at proper concentrations, to control $S$. frugiperda (GONZÁLEZ-CABRERA et al., 2011).

\section{Analysis of the integrity of $S$. frugiperda midguts \\ Isolates from the SUFT01 spore-crystal complex were highly toxic to $S$. frugiperda midgut}

cells, causing disruptions to the cellular integrity and the microvilli of the midgut columnar cells (Figure 5A). After $24 \mathrm{~h}$, an extensive disintegration in the columnar cells of the $S$. frugiperda midgut could be observed by transmission electron microscopy (Figure 5B). The disorganization of the cell cytoplasm caused by loss the microvilli in cells treated with Bt crystal and spore suspensions were visualized (Figure 5B). Endomembrane dilation, plasma membrane blebbing and cell fragmentation were observed, and they became more frequent as the post-inoculation time increased. Martins et al. (2008) described the effects of recombinant Cry1Ia protein action in the midgut of cotton boll weevil ,Anthonomus grandis (Boheman) (Coleoptera: Curculionidae) larvae, reporting morphologic changes in the midgut cells that were similar to those described in this work. Monnerat et al. (2007) obtained 27 isolates of $\mathrm{Bt}$ that killed $100 \%$ of $S$. frugiperda, Anticarsia gemmatalis (HÜBNER, 1818) and Plutella xylostella (LINNAEUS, 1758) 
larvae after 5 days in selective bioassays, and 19 isolates that exhibited $\mathrm{LC}_{50}$ values that were lower than those of the standard strain Btk HD-1. From our results, four isolates showed promise in controlling $S$. frugiperda larvae with $\mathrm{LC}_{50}$ values of
44.5, 74.0, 89.0 and $108 \mathrm{ng} / \mathrm{cm}^{2}$. However, the isolates SUFT01, SUFT02 and SUFT03 showed $\mathrm{LC}_{50}$ values that were less than the $285 \mathrm{ng} / \mathrm{cm}^{2}$ value for the Btk HD-1 strain reported in the work of (MONNERAT et al., 2007).
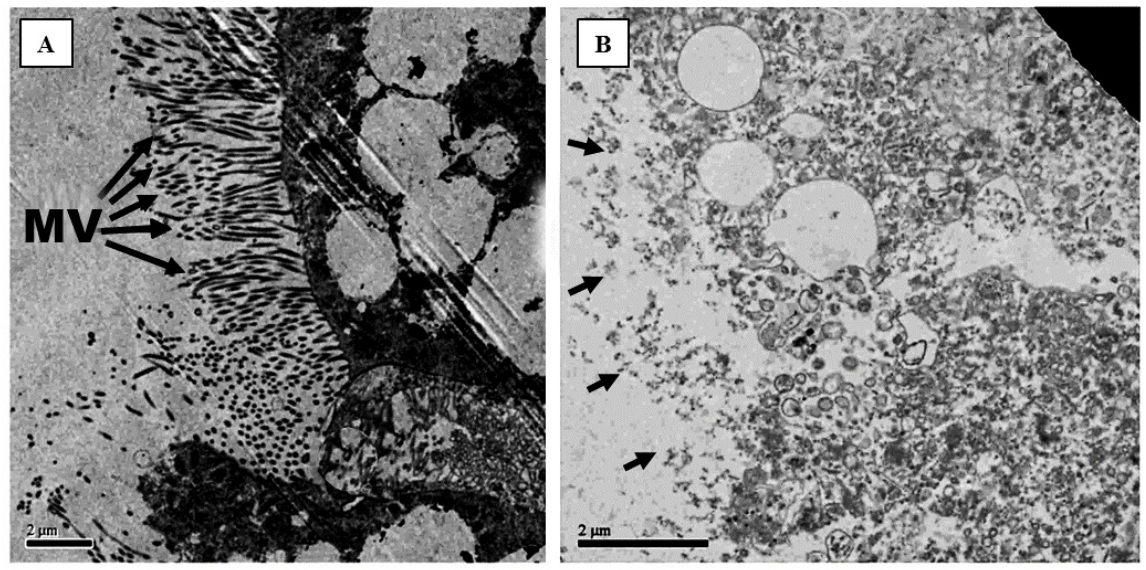

Figure 5. Toxicity effect of SUFT01 isolate suspensions in insect diets on Spodoptera frugiperda larvae midgut columnar cells. A. Midgut columnar cell of a S. frugiperda larva without the Bt treatment. Arrows indicate intact microvillus (MV). B. Midgut columnar cell of a larva fed an artificial diet containing the $\mathrm{Bt}$ suspension (24 $\mathrm{h}$ after inoculation). Arrows indicate the disorganization of the cell cytoplasm caused by loss of the microvillus in cell.

The search for alternative methods to control insect pests is necessary, mainly to reduce the use of conventional chemical control methods. Thus, new Bt isolates represent a source of new toxin genes with the potential to be introduced into the genome of plants of economic interest. Currently, numerous studies have been reported in several transgenic plants containing the cry genes of $B t$, such as potato (VALDERRAMA et al., 2007; KUMAR et al., 2010), tomato (LI et al., 2007), cotton (WU et al., 2005), rice (YE et al., 2003; YOUNG-JUN et al., 2004; GAO et al., 2010), corn (BELTAGI, 2008) and soybean (WALKER et al., 2000). Bt containing transgenic crop plants covered over 179,7 million hectares (corn, soybeans, cotton and potatoes) in worldwide and the highest increase was in Brazil, with 2 million hectares (James, 2015), this signifies the importance of this technology in controlling insect pests (ZHAO et al., 2005).

\section{CONCLUSION}

The high level of insecticidal activity of the isolates described in this work makes them excellent candidates for the control of $S$. frugiperda, and could provide alternatives in controlling insect pest populations that have developed resistance to chemical insecticides. Moreover, screening for new $\mathrm{Bt}$ isolates and their cry genes is important for the construction of cry gene databases for a possible future use in economically important transgenic crops.

\section{ACKNOWLEDGEMENTS}

This work was supported by the Federal University of Tocantins, Agronomy Graduate Program. It was financed by Coordenação de Aperfeiçoamento de Pessoal de Nível Superior (CAPES) and Conselho Nacional de Desenvolvimento Científico e Tecnológico (CNPq).

RESUMO: Spodoptera frugiperda (SMITH, 1797) (Lepidoptera: Noctuidae) afeta diversas culturas de grande interesse econômico, por exemplo, pode causar severas perdas em milho, arroz e sorgo. Neste estudo, foi realizada uma seleção e caracterização de isolados de Bacillus thuringiensis (BERLINER, 1911) com elevada atividade inseticida contra S. frugiperda. Cinquenta e dois isolados formadores de cristal B. thuringiensis que foram identificados a partir de 3384 colônias foram examinados e testados por PCR para a presença dos genes cry (cry1, cry1Aa, cry1Ab, cry1Ac, cry1D, cry2 e cry $2 \mathrm{Ab}$ ). Quatro isolados que apresentaram alta toxicidade contra $S$. frugiperda foram mostrados para abrigar os genes cry2. Os cristais foram analisados por microscopia eletrônica e mostraram formas bipiramidais e cúbicas. Os valores da 
concentração letal $\left(\mathrm{CL}_{50}\right)$ destes quatro isolados foram de 44,5 ng / cm² (SUFT01), 74,0 ng / cm² (SUFT02), 89,0 ng / cm² (SUFT03) e $108 \mathrm{ng} / \mathrm{cm}^{2}$ (suft 04) para larvas recém-eclodidas de $S$. frugiperda. Uma análise ultra-estrutural das células do intestino médio de $S$. frugiperda incubadas com complexo esporo-cristal do isolado SUFT01 mostrou rupturas na integridade celular e microvilosidades das células cilíndricas do intestino médio. Neste estudo, o alto nível de atividade inseticida de isolados os torna excelentes candidatos para o controlo de $S$. frugiperda, e pode proporcionar alternativas no controle destas populações de pragas, bem como a formação de novos bioinsecticidas. insetos.

PALAVRAS-CHAVE: Cry proteína. Lepidópteros. Entomopatógeno. Inseticida microbiano. Controle de

\section{REFERENCES}

ABBOTT, W. S. A method of computing the effectiveness of an insecticide. Journal of Economic Entomology, College Park, v. 18, n. 1, p. 265-267, 1925. http://dx.doi.org/10.1093/jee/18.2.265a

AGAISSE, H.; LERECLUS, D. How does Bacillus thuringiensis produce so much insecticidal crystal protein? Journal of Bacteriology, Paris, v. 177, n. 21, p. 6027-6032, 1995.

ARANDA, E.; SÁNCHES, J.; PEFEROEN, N.; GUERECA, L.; BRAVO, A. Interaction of Bacillus thuringiensis crystal protein with the midgut epithelial cells of Spodoptera frugiperda (Lepidoptera: Noctuidae). Journal of Invertebrate Pathology, Cuernavaca, v. 68, n. 3, p. 203-212, 1996. http://dx.doi.org/10.1006/jipa.1996.0087

ARRIETA, G.; ESPINOZA, A. M. Characterization of a Bacillus thuringiensis strain collection isolated from diverse Costa Rican natural ecosystems. Revista de Biología Tropical, San José, v. 54, n. 1, p. 13-27, 2006. http://dx.doi.org/10.15517/rBt.v54i1.13981

ARMENGOL, G.; ESCOBAR, M. C.; MALDONADO, M. E; ORDUZ, S. Diversity of Colombian strains of Bacillus thuringiensis with insecticidal activity against dipteran and lepidopteran insects. Journal of Applied Microbiology, Medellín, v. 102, n. 1, p. 77-88, 2007. http://dx.doi.org/10.1111/j.1365-2672.2006.03063.x

ASOKAN, R.; SWAMY, H. M. M.; ARORA, D. K. Screening, Diversity and Partial Sequence Comparison of Vegetative Insecticidal Protein (vip3A) Genes in the Local Isolates of Bacillus thuringiensis Berliner. Current Microbiology, Bangalore, v. 64, n. 4, p. 365-370, 2012. http://dx.doi.org/10.1007/s00284-011-0078-z

AZZOUZ, H.; KEBAILI-GHRIBI, J.; FARHAT-TOUZRI, D. B.; TOUNSI, F. S., JAOUA, S. Selection and characterization of an HD1-like Bacillus thuringiensis isolate with a high insecticidal activity against Spodoptera littoralis (Lepidoptera: Noctuidae). Pest Management Science, Sfax, v. 70, n. 8, p. 1192-1201, 2014.

BELTAGI, M. S. Molecular responses of $B t$ transgenic corn (Zea mays L.) plans to salt ( $\mathrm{NaCl})$ stress. Australian Journal of Crop Science, Ismailia, v. 2, n. 2, p. 57-63, 2008.

BEN-DOV, E.; ZARITSKY, A.; DAHAN, E.; BARAK, Z.; SINAI, R.; MANASHEROB, R.; KHAMRAEV, A.; TROITSKAYA, E.; DUBITSKY, A.; BEREZINA, N.; MARGALITH, Y. Extended screening by PCR for seven cry-group genes from field-collected strains of Bacillus thuringiensis. Applied and Environmental Microbiology, Beersheba, v. 63, n. 12, p. 4883-4890, 1997.

BERLINER, E. 1911. Über die Schlafsucht der Mehlmottenraupe. Z. Gesante Getreidewesen (Berlin). 3: 6370.

BERÓN, C. M.; SALERNO, G. L. Characterization of Bacillus thuringiensis isolates from Argentina that are potentially useful in insect pest control. Biological Control, Mar Del Plata, v. 51, n. 6, p. 779-794, 2006. http://dx.doi.org/10.1007/s10526-006-9018-4 
BOREGAS, K. G. B.; MENDES, S. M.; WAQUIL, J. M.; FERNANDES, G. W. Estádio de adaptação de Spodoptera frugiperda (JE Smith)(Lepidoptera: Noctuidae) em hospedeiros alternativos. Bragantia, v. 72, n. 1, p. 61-70, 2013. http://dx.doi.org/10.1590/S0006-87052013000100009

BRAGA MAIA, J.; ANDRADE, G.; LOPES, R.; LASMAR, O.; SANTOS, M. I. Effects of insecticides used in corn on immature stages of Trichogramma atopovirilia (Hymenoptera: Trichogrammatidae). Revista Colombiana de Entomología, v. 39, n. 2, p. 205-210, 2013.

BRAVO, A.; SARABIA, S.; LOPEZ, L.; ABARCA, C.; ORTIZ, A.; ORTIZ, M.; LINA, L.; VILLALOBOS, F.J.; PEÑA, G.; NUÑEZ-VALDEZ, M. E.; SOBERÓN, M; QUINTERO, R. Characterization of cry genes in a mexican Bacillus thuringiensis strain collection. Applied and Environmental Microbiology, Cuernavaca, v. 64, n. 12, p. 4965-4972, 1998.

CERÓN, J.; ORTIZ, A.; QUINTERO, R.; GÜERECA, L.; BRAVO, A. Specific PCR primers directed to identify cryI and cryIII genes within a Bacillus thuringiensis strain collection. Applied and Environmental Microbiology, Bogota, v. 61, n. 11, p. 3826-3831, 1995.

CHAK, K. F.; CHAO, D. C.; TSENG, M. Y.; KAO, S. S.; TUAN, S. J.; FENG, T. Y. Determination and distribution of cry-type genes of Bacillus thuringiensis isolates from Taiwan. Applied and Environmental Microbiology, Taiwan, v. 60, n. 7, p. 2415-2420, 1994.

CHENG, P.; WU, L.; ZINIU, Y.; ARONSON, A. Subspecies-dependent regulation of Bacillus thuringiensis protoxin genes. Applied and Environmental Microbiology, West Lafayette, v. 65, p. 1849-1853, 1999.

DIAS, S. C.; SAGARDOY, M. A.; SILVA, S. F.; DIAS, J. M. C. S. Characterization and pathogenic evaluation of Bacillus thuringiensis and Bacillus sphaericus isolates from Argentinean soils. Biological Control, Bahía Blanca, v. 44, n. 1, p. 59-71, 1999.

FINNEY, D. J. Probit analysis, Cambridge University Press, Cambridge, England, 1971.

FRANKENHUYZEN, K. V. Insecticidal activity of Bacillus thuringiensis crystal proteins. Journal of Invertebrate Pathology, Ontario, v. 101, n. 1, p. 1-16, 2009. http://dx.doi.org/10.1016/j.jip.2009.02.009

GALLO, D.; NAKANO, O.; NETO, S.S.; CARVALHO, R. P. L.; BATISTA, G.C.; FILHO, E. B.; PARRA, J. R. P.; ZUCCHI, R. A.; ALVES, S. B.; VENDRAMIM, J. D.; MARCHINI, L. C.; LOPES J. R. S.; OMOTO, C. Entomologia agrícola, Piracicaba, FEALQ, São Paulo,. 920p, 2002.

GAO, M.; LI, R.; DAI, S.; WU, Y.; YI, D. Diversity of Bacillus thuringiensis isolates from soil in China and their pesticidal activities. Biological Control, Wuhan, v. 44, n. 3, p. 380-388, 2008.

http://dx.doi.org/10.1016/j.biocontrol.2007.11.011

GAO, Y.; HU, Y.; FU, Q.; ZHANG, J. OPPERT, B., LAI, F. PENG, Y., ZHANG, Z. 2010. Screen of Bacillus thuringiensis toxins for transgenic rice to control Sesamia inferens and Chilo suppressalis. Journal of Invertebrate Pathology, Hangzhou, v. 105, n. 1, p. 11-15, 2010. http://dx.doi.org/10.1016/j.jip.2010.05.002

GHRIBI, D.; ZOUARI, N.; TRIGUI, W.; JAOUA, S. Use of sea water as salts source in starch- and soya beanbased media, for the production of Bacillus thuringiensis bioinsecticides. Process Biochemistry, Tunisia, v. 42, n. 3, p. 374-378, 2007. http://dx.doi.org/10.1016/j.procbio.2006.09.006

GONZÁLEZ-CABRERA, J.; MOLLÁ, O.; MONTÓN, H.; URBANEJA, A. Efficacy of Bacillus thuringiensis (Berliner) for controlling the tomato borer, Tuta absoluta (Meyrick) (Lepidoptera: Gelechiidae). Biological Control, Moncada, v. 56, n. 1, p. 71-80, 2011. http://dx.doi.org/10.1007/s10526-010-9310-1

HONGYU, Z.; ZINIU, Y.; WANGXI, D. Isolation, distribution and toxicity of Bacillus thuringiensis from warehouses in China. Crop Protection, Wuhan, v. 19, n. 7, p. 449-454, 2000. http://dx.doi.org/10.1016/S02612194(00)00036-3 
HIRE, R. S.; MAKDE, R. D.; DONGRE, T. K.; D'SOUZA, S. F. Characterization of the cry1Ac17 gene from an indigenous strain of Bacillus thuringiensis subsp. Kenyae. Current Microbiology, Mumbai, v. 57, p. 570574, 2008. http://dx.doi.org/10.1007/s00284-008-9244-3

JAMES, C. 20th Anniversary (1996 to 2015) of the Global Commercialization of Biotech Crop Highlights in 2015. ISAAA Brief, n. 51, 2015.

JARA, S.; MADUELL, P.; ORDUZ, S. Diversity of Bacillus thuringiensis strains in the maize and bean phylloplane and their respective soils in Colombia. Journal of Applied Microbiology, Medellín, v. 101, n. 1, p. 117-124, 2006. http://dx.doi.org/10.1111/j.1365-2672.2006.02901.x

KALFON, A.; LARGET-THIÉRY, I.; CHARLES, J. F.; BARJAC, H. Growth, sporulation and larvicidal activity of Bacillus sphaericus. Applied Microbiology and Biotechnology, Paris, v. 18, n. 3, p. 168-173, 1983. http://dx.doi.org/10.1007/BF00498040

KUMAR, M.; CHIMOTE, V.; SINGH, R.; MISHRA, G. P.; NAIK, P. S.; PANDEY, S. K.; CHAKRABARTI, $\mathrm{S}$. K. Development of $B t$ transgenic potatoes for effective control of potato tuber mothby using crylAb gene regulated by GBSS promoter. Crop Protection, Jammu \& Kashmir, v. 29, n. 2, p. 121-127, 2010.

LECADET, M. M.; CHAUFAUX, J.; RIBIER, J.; LERECLUS, D. Construction of novel Bacillus thuringiensis lsolates with different insecticidal activities by transduction and transformation. Applied and Environmental Microbiology, Paris v. 58, n. 3, p. 840-849, 1992.

LI, X.; WEI, J.; TAN, A.; AROIAN, R. V. Resistance to root-knot nematode in tomato roots expressing a nematicidal Bacillus thuringiensis crystal protein. Plant Biotechnology Journal, San Diego, v. 5, n. 4, p. 455464, 2007. http://dx.doi.org/10.1111/j.1467-7652.2007.00257.x

LIMA, G. M. S.; AGUIAR, R. W. S.; CORRÊA, R. F. T.; MARTINS, E. S.; GOMES, A. C. M.; NAGATA, T.; DE-SOUZA, M. T.; MONNERAT, R. G.; RIBEIRO, B. M. Cry2A toxins from Bacillus thuringiensis expressed in insect cells are toxic to two lepidopteran insects. World Journal of Microbiology and Biotechnology, University of Brasília, Brasília, v. 24, n. 12, p. 2941-2948, 2008.

LUTTRELL, R. G.; WAN, L.; KNIGHTEN, K. Variation in susceptibility of noctuid (Lepidoptera) larvae attacking cotton and soybean to purified endotoxin proteins and commercial formulations of Bacillus thuringiensis. Journal of Economic Entomology, Starkville, v. 92, n. 1, p. 21-32, 1999. http://dx.doi.org/10.1093/jee/92.1.21

MARTINS, E. S.; AGUIAR, R.W.S.; MARTINS, N. F.; MELATTI, V. M.; FALCÃO, R.; GOMES, A. C. RIBEIRO, B. M.; MONNERAT, R. G. Recombinant Cry1Ia protein is highly toxic to cotton boll weevil (Anthonomus grandis Boheman) and fall armyworm (Spodoptera frugiperda). Journal of Applied Microbiology, University of Brasília, Brasília, v. 104, n. 5, p. 1363-1371, 2008.

MASSON, L.; ERLANDSON, M.; PUZSTAI-CAREY, M.; BROUSSEAU, R.; JUAREZ-PEREZ, V.; FRUTOS, R.; A holistic approach for determining the entomopathogenic potential of Bacillus thuringiensis strains. Applied and Environmental Microbiology, Montréal, v. 64, n. 12, p. 4782-4788, 1998.

MONNERAT, R. G.; SILVA, S. F.; SILVA-WERNECK, J. O. Catálogo do banco de germoplasma de bactérias entomopatogênica do gênero Bacillus. Documentos, 60, Brasília: Embrapa-Cenargen, 65p., 2001. http://dx.doi.org/10.1016/j.biocontrol.2006.11.008

MONNERAT, R. G.; BATISTA, A. C.; DE MEDEIROS, P. T.; MARTINS, E. S.; MELATTI, V. M.; PRAÇA, L. B.; DUMAS, V. F.; MORINAGA, C.; DEMO, C.; GOMES, A. C. M.; FALCÃO, R.; SIQUEIRA, C. B.; SILVA-WERNECK, J. O.; BERRY, C. Screening of Brazilian Bacillus thuringiensis isolates active against Spodoptera frugiperda, Plutella xylostella and Anticarsia gemmatalis. Biological Control, Brasília, v. 41, n. 3, p. 291-295, 2007. 
PRAÇA, L. B.; BATISTA, A. C.; MARTIN, E. S.; SIQUEIRA, C. B.; DIAS, D. G. S.; GOMES, A. C. M. M.; FALCÃO, R.; MONNERAT, R. G. Estirpes de Bacillus thuringiensis efetivas contra insetos das ordens Lepidoptera, Coleoptera e Diptera. Pesquisa Agropecuária Brasileira, Brasília, v. 39, n. 1, p. 11-16, 2004. http://dx.doi.org/10.1590/S0100-204X2004000100002

PIMENTEL, D. Environmental and economic costs of the application of pesticides primarily in the united states. Environment, Development and Sustainability, Netherlands, v.7: p.229-252, 2005. http://dx.doi.org /10.1007/s10668-005-7314-2

SCHNEPF, E.; CRICKMORE, N.; RIE, J. V.; LERECLUS, D.; BAUM, J.; FEITELSON, J.; ZEIGLER, D. R.; DEAN, D. H.; 1998. Bacillus thuringiensis and its pesticidal crystal proteins. Microbiology and Molecular Biology Reviews, San Diego, v. 62, n. 3, p. 775-806, 1998.

SAMBROOK, J.; RUSSEL, D.W. Molecular Clonning: A Laboratory Manual. 3.rd Edition. Woodbury, New York EUA: Cold Spring Harbor Laboratory Press, 2344 p., 2001.

STEWART, G. S. A. B.; JOHNSTONE, K.; HAGELBERG, E.; ELLAR, D. J. Commitment of bacterial spores to germinate. Biochemical Journal, London, v. 198, p. 101-106, 1981. http://dx.doi.org/10.1042/bj1980101

SAADAOUI, I.; ROUIS, S.; JAOUA, S. A new Tunisian strain of Bacillus thuringiensis kurstaki having high insecticidal activity and $\delta$-endotoxin yield. Archives of Microbiology, Sfax, v. 191, n. 4, p. 341-348, 2009.

SAMBROOK, J.; MACCALLUM, P.; RUSSEL, D. Molecular cloning: A laboratory manual, 3 nd ed. Cold Springs Harbour Press, NY, ISBN 0- 87969-577-3, p. 2344. 2001.

SANTOS, K. B.; NEVES, P.; MENEGUIM, A. M.; SANTOS, R. B.; SANTOS, W. J.; BOAS, G. V.; DUMAS, V.; MARTINS, E.; PRAÇA, L. B.; QUEIROZ, P.; BERRY, C.; MONNERAT, R. Selection and characterization of the Bacillus thuringiensis strains toxic to Spodoptera eridania (Cramer), Spodoptera cosmioides (Walker) and Spodoptera frugiperda (Smith) (Lepidoptera: Noctuidae). Biological Control, Londrina, v. 50, n. 2, p. 157-163, 2009. http://dx.doi.org/10.1016/j.biocontrol.2009.03.014

SANTOS-AMAYA, O. F.; TAVARES, C. S.; MONTEIRO, H. M.; TEIXEIRA, T. P. M.; GUEDES, R. N. C., ALVES, A. P.; PEREIRA, E. J. G. Genetic basis of Cry1F resistance in two Brazilian populations of fall armyworm, Spodoptera frugiperda. Crop Protection, v. 81, p. 154-162, 2016.

http://dx.doi.org/10.1016/j.cropro.2015.12.014

SONG, L.; GAO, M.; DAI, S.; WU, Y.; YI, D.; LI, R. Specific activity of a Bacillus thuringiensis strain against Locusta migratoria manilensis. Journal of Invertebrate Pathology, Wuhan, v. 98, n. 2, p. 169-176, 2008. http://dx.doi.org/10.1016/j.jip.2008.02.006

SU, X.; SHU, C.; ZHANG, J.; HUANG, D.; TAN, J.; SONG, F. Identification and Distribution of Bacillus thuringiensis Isolates from Primeval Forests in Yunnan and Hainan Provinces and Northeast Region of China. Agricultural Sciences in China, Beijing, v. 6, n. 11, p. 1343-1351, 2007. http://dx.doi.org/10.1016/S16712927(07)60182-5

TAILOR, R.; TIPPETT, J.; GIBB, G.; PELLS, S.; JORDAN, L.; ELY, S. Identification and characterization of a novel Bacillus thuringiensis delta-endotoxin entomocidal to coleopteran and lepidopteran larvae. Molecular Microbiology, Berkshire, v. 6, n. 9, p. 1211-1217, 1992. http://dx.doi.org/10.1111/j.1365-2958.1992.tb01560.x

TODOROVA, S.; KOZHUHAROVA, L. Characteristics and antimicrobial activity of Bacillus suBtilis strains isolated from soil. World Journal of Microbiology and Biotechnology, Razgrad, v. 26, n. 7, p. 1207-1216, 2010.

TOUNSI, S.; DAMMAK, M.; ZOUARI, N.; REBAÎ, A.; JAOUA, S. Evidence of the effect of $\delta$-endotoxin ratio in Bacillus thuringiensis crystals on the toxicity against Ephestia kuehniella. Biological Control, Sfax, v. 37, p. 243-246, 2006. 
URIBE, D.; MARTINEZ, W.; CERÓN, J. Distribution and diversity of cry genes in native lsolates of Bacillus thuringiensis oBtained from different ecosystems from Colombia. Journal of Invertebrate Pathology, Santafe de Bogotá, v. 82, n. 2, p. 119-127, 2003.

VALDERRAMA, A. M.; VEÁSQUEZ, N.; RODRÍGUEZ, E.; ZAPATA, A.; ZAIDI, M. A.; ALTOSAAR, I.; ARANGO, R. Resistance to Tecia solanivora (Lepidoptera: Gelechiidae) in three transgenic varieties of potato expressing Bacillus thuringiensis CrylAc protein. Journal of Economic Entomology, Medellin, v. 100, n. 1, p. 172-179. 2007. http://dx.doi.org/10.1603/0022-0493(2007)100[172:RTTSLG]2.0.CO;2

http://dx.doi.org/10.1093/jee/100.1.172

VALICENTE, F. H.; PICOLI, E. A. T.; VASCONCELOS, M. J. V.; CARNEIRO, N. P.; CARNEIRO, A. A.; GUIMARÃES, C. T.; LANA, U. G. 2010. Molecular characterization and distribution of Bacillus thuringiensis cryl genes from Brazilian isolates effective against the fall armyworm, Spodoptera frugiperda. Biological Control, Sete Lagoas, v. 53, n. 3, p. 360-366, 2010.

WALKER, D. R.; ALL, J. N.; MCPHERSON, R. M.; BOERMA, H. R.; PARROTT, W. A. Field evaluation of soybean engineered with a synthetic crylAc transgene for resistance to corn earworm, soybean looper, velvet bean caterpillar (Lepidoptera: Noctuidae), and lesser cornstalk borer (Lepidoptera: Pyralidae). Journal of Economic Entomology, Athens, v. 93, n. 3, p. 613-622, 2000. http://dx.doi.org/10.1603/0022-0493-93.3.613

WANG, J.; BOETS, A.; RIE, J. V.; REN, G. Characterization of cry1, cry2, and cry9 genes in Bacillus thuringiensis isolates from China. Journal of Invertebrate Pathology, Tianjin, v. 82, n. 1, p. 63-71, 2003. http://dx.doi.org/10.1016/S0022-2011(02)00202-1

WU, K.; MU, W.; LIANG, G.; GUO, Y. Regional reversion of insecticide resistance in Heliocoverpa armigera (Lepidoptera: Noctuidae) is associated with the use of $B t$ cotton in northern China. Pest Management Science, Beijing, v. 61, n. 5, p. 491-498, 2005. http://dx.doi.org/10.1002/ps.999

YE, G. Y.; YAO, H. W.; SHU, Q. Y.; CHENG, X.; HU, C.; XIA, Y. W.; GAO, M. W.; ALTOSAAR, I. High levels of sTable resistance in transgenic rice with a crylAb gene from Bacillus thuringiensis Berliner to rice leaffolder, Cnaphalocrocis medinalis (Guenee) under field conditions. Crop Protection, Hangzhou, v. 22, n. 1, p. 171-178, 2003. http://dx.doi.org/10.1016/S0261-2194(02)00142-4

YONG-JUN, Z.; HONG-YING, Z.; KONG-MING, W.; KUI-JUN, Z.; YU-FA, P.; YU-YUAN, G. Expression of Cry1Ac protein in CrylAc/CpTI transgenic rice and its resistance in different stages to Chilo suppressalis. Chinese Journal of Agricultural Biotechnology. Beijing, v. 12, n. 1, p. 7-79, 2004.

http://dx.doi.org/10.1079/CJB200429

ZHAO, J. Z.; CAO, J.; COLLINS, H. L.; BATES, S. L.; ROUSH, R. T.; EARLE, E. D.; SHELTON, A. M. Concurrent use of transgenic plants expressing a single and two Bacillus thuringiensis genes speeds insect adaptation to pyramided plants. Proceedings of the National Academy of Sciences of the United States of America, Urbana, v. 102, n. 24, p. 8426-8430, 2005. http://dx.doi.org/10.1073/pnas.0409324102

ZOUARI, N.; ACHOUR, O.; JAOUA, S. Production of delta-endotoxin by Bacillus thuringiensis subsp. kurstaki and overcoming of catabolite repression by using highly concentrated gruel and fish meal media in 2and $20 \mathrm{dm}^{3}$ fermenters. Journal of Chemical Technology and Biotechnology, Sfax, v. 77, n. 8, p. 877-882, 2002. 